Supporting information for

\title{
Hydrophobic and Bulk Polymerizable Protein-based \\ Elastomers Compatibilized with Surfactants
}

W. Y. Chan ${ }^{a}$, E. J. King ${ }^{b}$, and B. D. Olsen ${ }^{a}$

aDepartment of Chemical Engineering, Massachusetts Institute of Technology, 77

Massachusetts Avenue, Cambridge, Massachusetts 02139, United States

bWellesley College, 106 Central St, Wellesley, Massachusetts 02481, United States

AUTHOR INFORMATION

Corresponding Author

*Email: bdolsen@mit.edu 
(a)

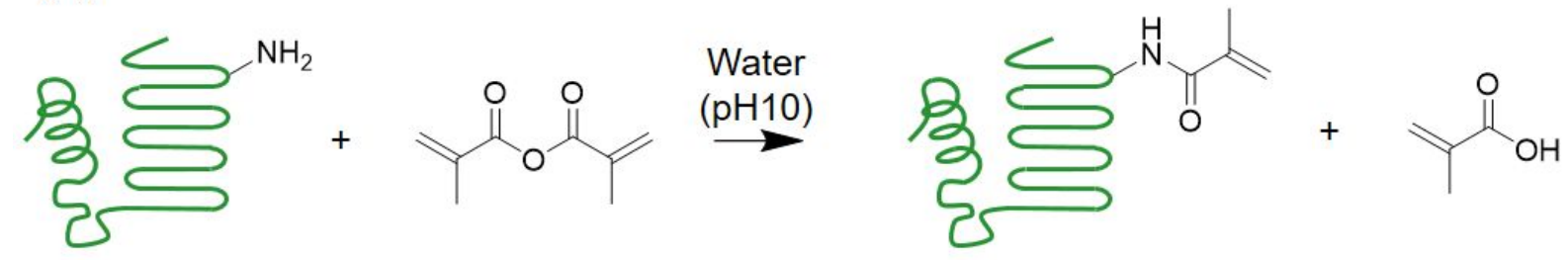

(b)
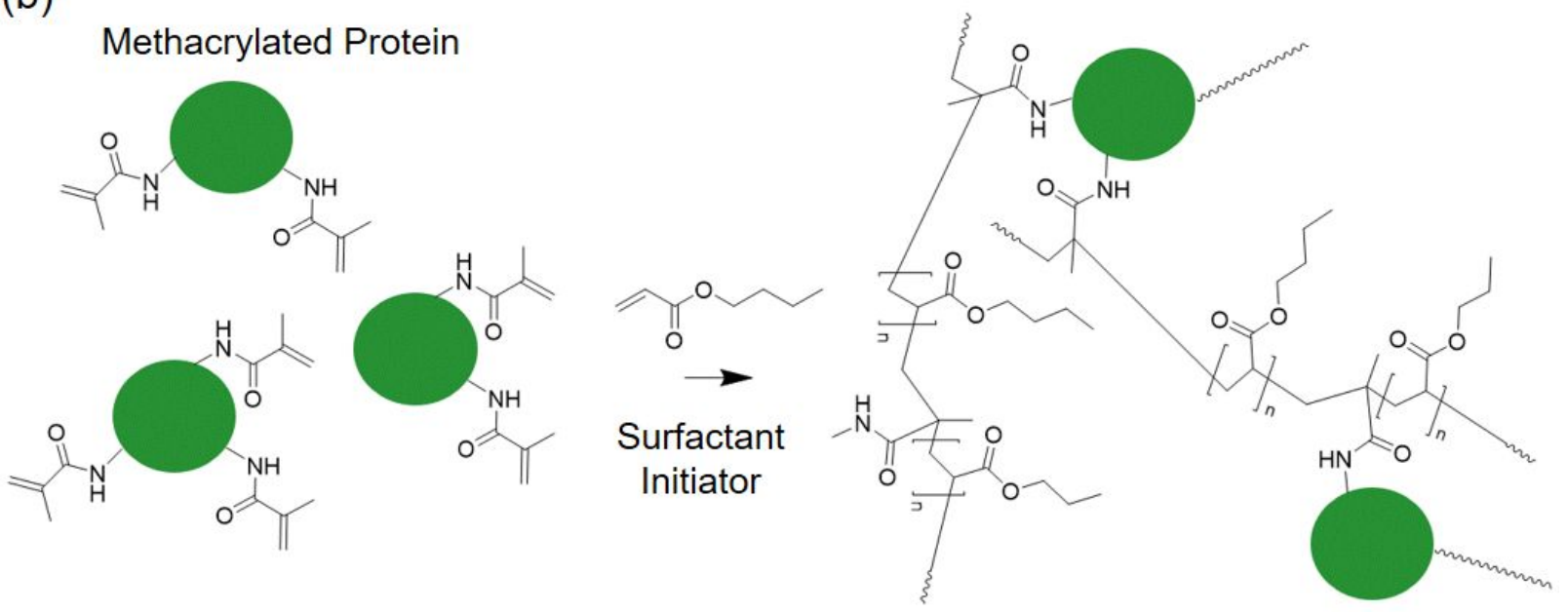

(c)
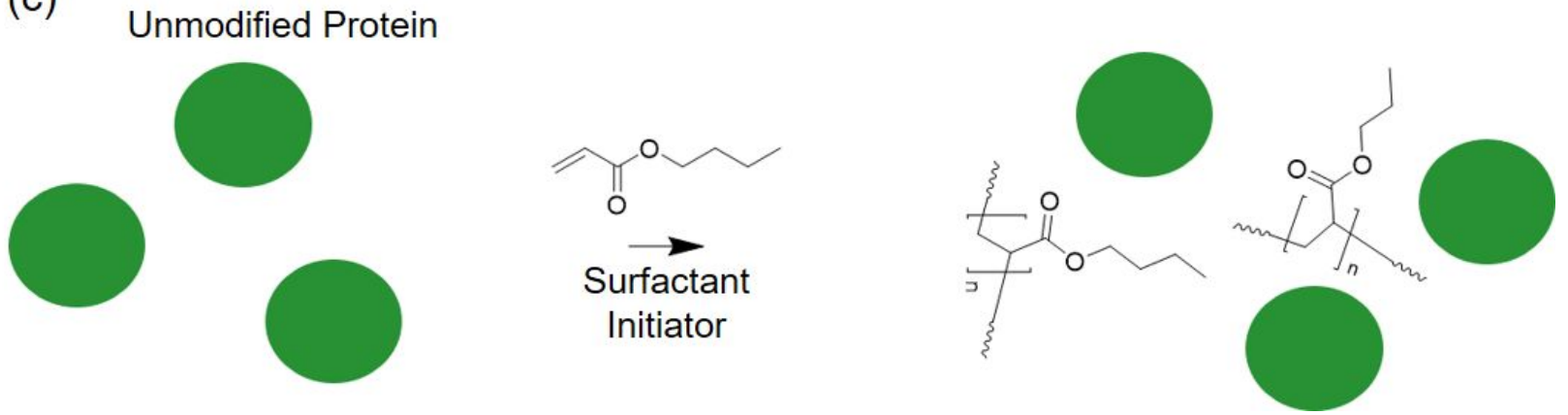

Scheme S1 (a) Reaction of proteins with methacrylic anhydride to install polymerizable methacrylamide groups onto proteins. (b) Copolymerization of methacrylated protein with an acrylate comonomer results in formation of crosslinked copolymer, in the case where proteins have two or more polymerizable groups. (c) Polymerization of acrylate monomer in the presence of an unmodified protein results in a protein-polymer blend. 
Table S1. Mechanical properties of materials melt polymerized at $1000 \mathrm{psi}$ and $250 \mathrm{psi}$. Both sets of materials are comprised of protein, surfactant, and n-butyl acrylate at a ratio of 1:1:2.

\begin{tabular}{|l|l|l|c|c|}
\hline Molding Pressure (psi) & $\begin{array}{l}\text { Modulus } \\
(\mathrm{MPa})\end{array}$ & $\begin{array}{l}\text { Tensile } \\
\text { Strength } \\
(\mathrm{MPa})\end{array}$ & $\begin{array}{l}\text { Elongation- } \\
\text { at-Break }(\%)\end{array}$ & $\begin{array}{l}\text { Toughness } \\
\left(\mathrm{MJ} / \mathrm{m}^{2}\right)\end{array}$ \\
\hline 1000 & $8.2 \pm 0.9$ & $1.4 \pm 0.4$ & $110 \pm 50$ & $1.2 \pm 0.5$ \\
\hline 250 & $8.1 \pm 1.5$ & $1.4 \pm 0.2$ & $94 \pm 19$ & $0.93 \pm 0.19$ \\
\hline
\end{tabular}

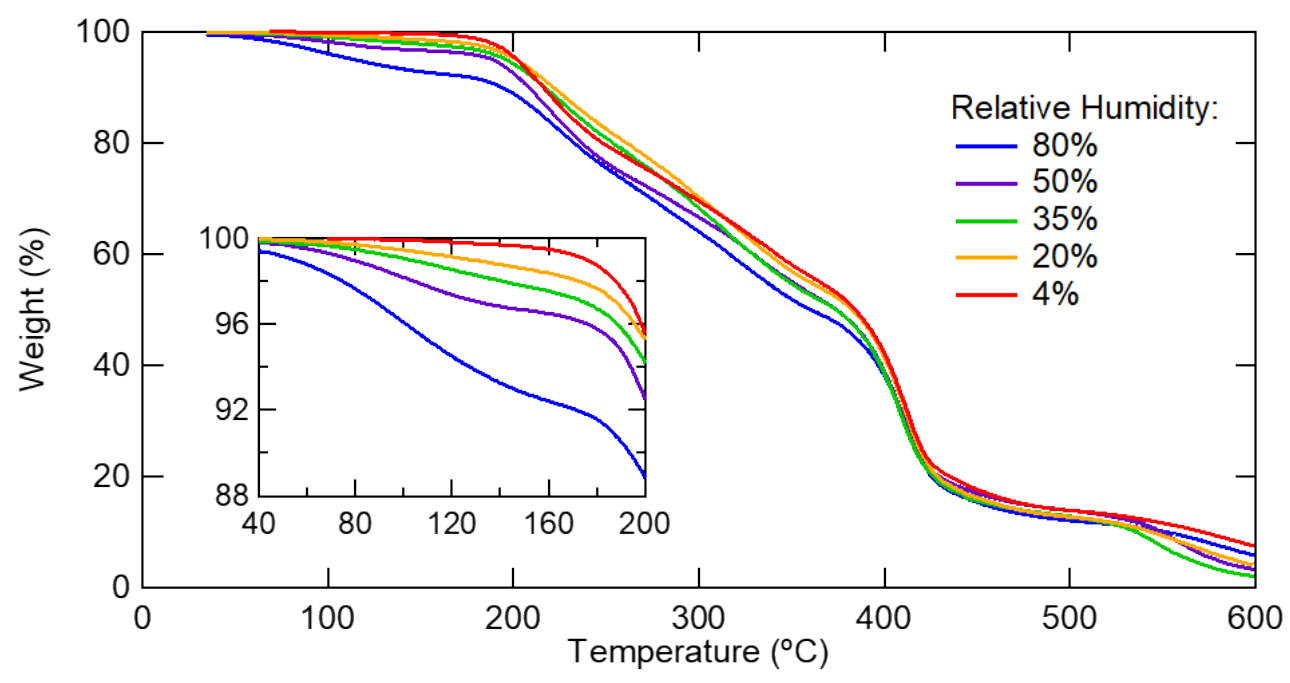

Figure S1. TGA curves for a protein-surfactant-polyacrylate (WPI-BAC-n-BA) copolymer conditioned at various relative humidity levels. Inset shows mass losses below $200{ }^{\circ} \mathrm{C}$. Losses below $150{ }^{\circ} \mathrm{C}$ were attributed to absorbed moisture. 
(a)

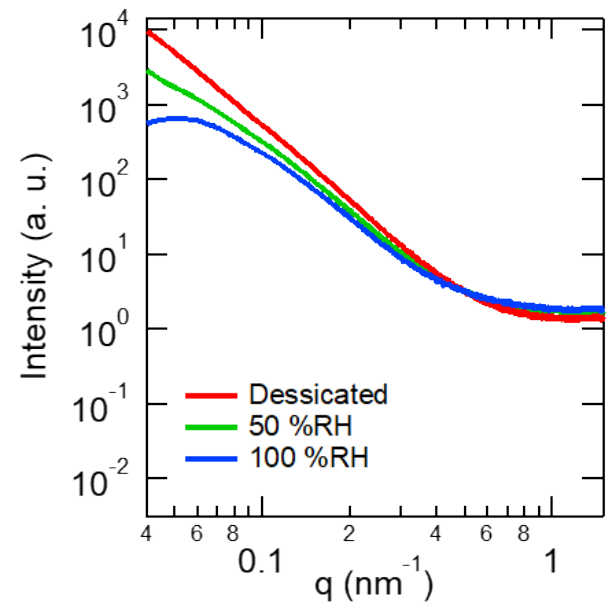

(b)

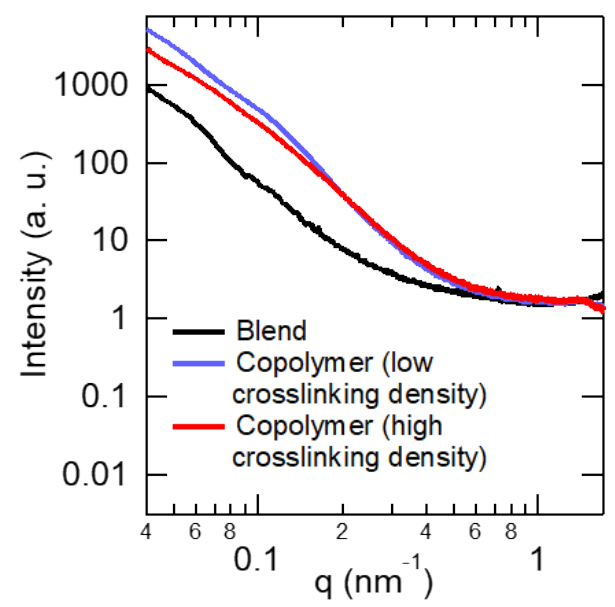

Figure S2. (a) SAXS curves for a crosslinked whey protein isolate- benzalkonium chloridepoly(n-butyl acrylate) conditioned at various relative humidity prior to measurement. Protein: surfactant: comonomer ratio is $1: 1: 2$, and the proteins are modified to have roughly 6 methacrylamide groups per protein. (b) Comparison between a blend and copolymers of various crosslinking densities. The blend was prepared with unmodified proteins, while the low and high crosslinking density copolymers were prepared with proteins modified to have roughly 1.2 and 6 methacrylamide groups respectively.

Table S2. Comparison of WAXS peak positions for benzalkonium chloride, whey proteinbenzalkonium chloride complex, whey protein-benzalkonium chloride- poly(n-butyl acrylate) blend and copolymer.

\begin{tabular}{|l|c|c|c|}
\hline Material & $\begin{array}{l}\text { Peak Center } \\
\left(\mathrm{nm}^{-1}\right)\end{array}$ & d-Spacing (nm) & $\begin{array}{l}\text { Full Width Half Max } \\
(\mathrm{nm})\end{array}$ \\
\hline Surfactant only & 2.29 & 2.74 & 0.61 \\
\hline Protein-surfactant complex & 1.98 & 3.18 & 0.99 \\
\hline $\begin{array}{l}\text { Protein-surfactant- } \\
\text { polyacrylate blend }\end{array}$ & 2.15 & 2.92 & 0.72 \\
\hline $\begin{array}{l}\text { Protein-surfactant- } \\
\text { polyacrylate copolymer (6 } \\
\text { methacrylamide groups per } \\
\text { protein) }\end{array}$ & 2.21 & 2.85 & 0.91 \\
\hline
\end{tabular}


(a)

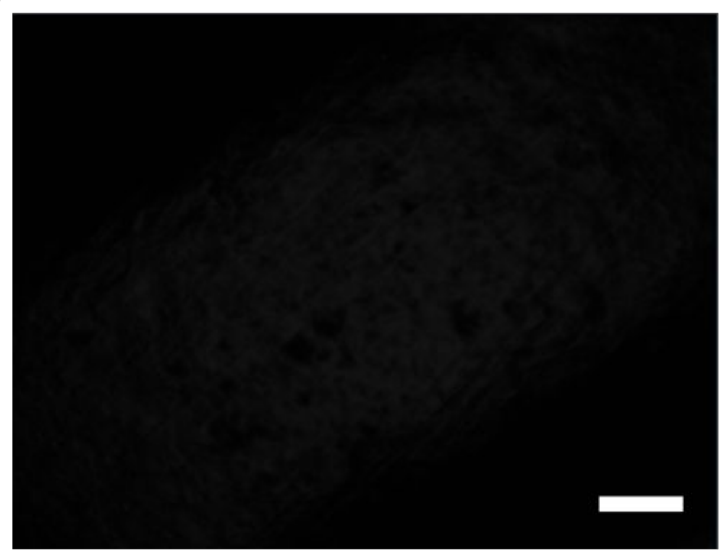

(c)

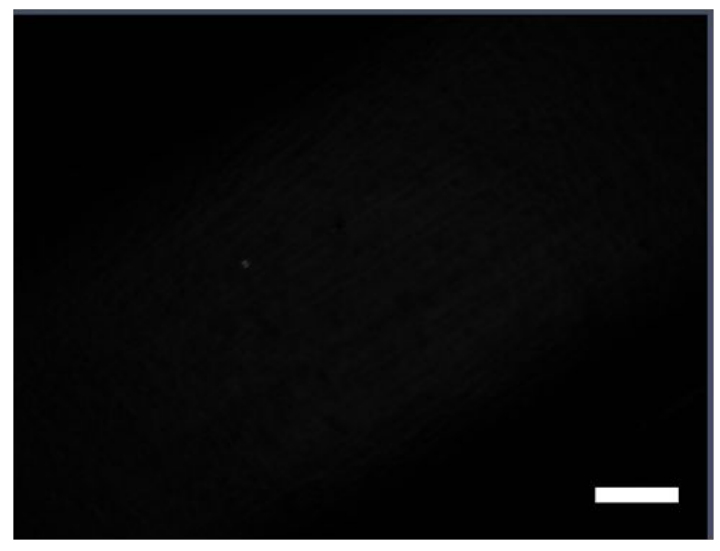

(b)

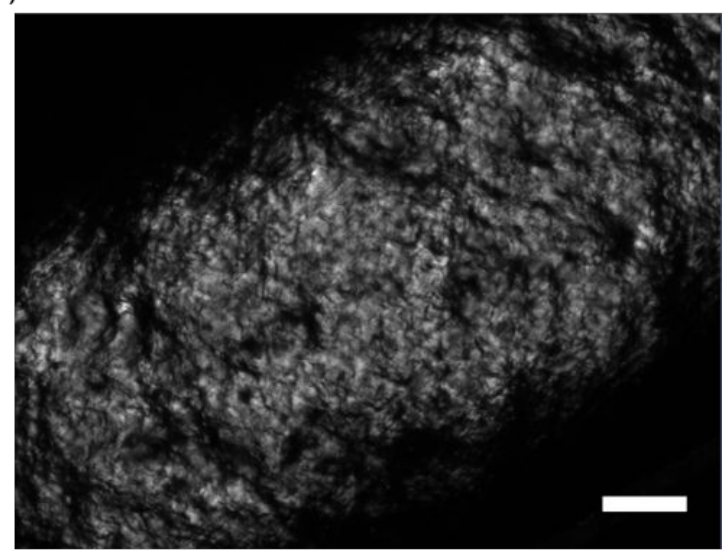

(d)

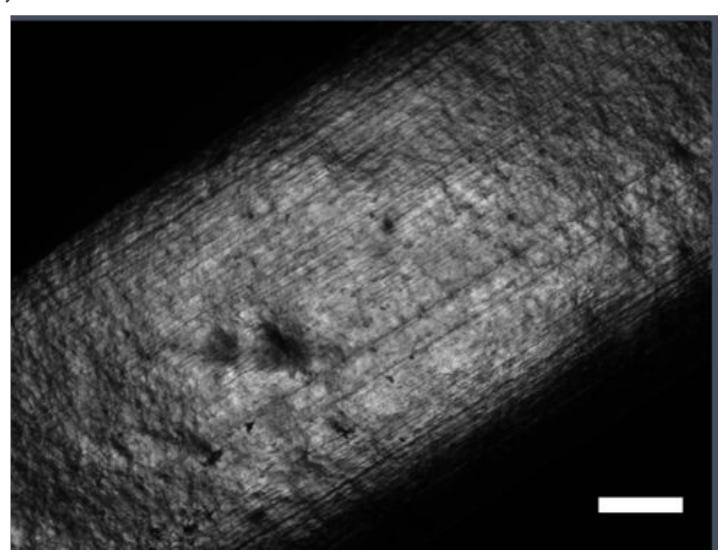

Figure S3. Microscope images under a cross polarizer of the whey protein-benzalkonium chloride complex at a mass ratio of $1: 1$ at (a) $0 \%$ and $50 \%$ strain. Images of the whey proteinbenzalkonium chloride-polyacrylate at a mass ratio of 1:1:2 at (a) $0 \%$ and (b) $50 \%$ strain. Scale bar: $200 \mu \mathrm{m}$. 


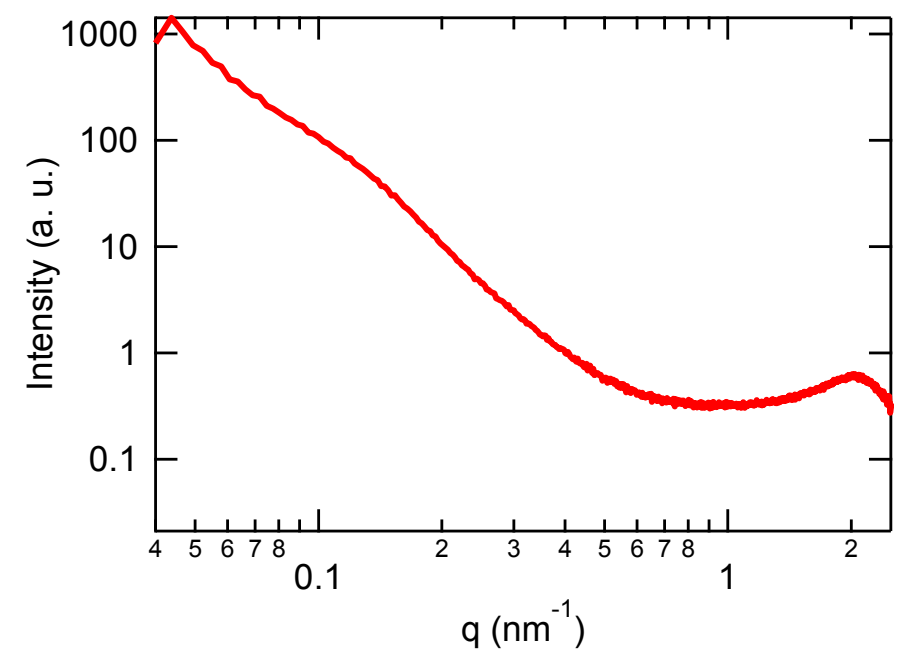

Figure S4. SAXS curve for a whey protein-benzalkonium chloride complex. Protein: surfactant ratio is $1: 1$.

Table S3. Comparison of mechanical properties. The crosslinked copolymer was prepared using whey protein with an average of 6 methacrylamide functionalities and a protein: surfactant: n-butyl acrylate ratio of 1:1:2. Complexes were prepared at a protein: surfactant ratio of $1: 1$.

\begin{tabular}{|l|c|c|c|c|}
\hline & $\begin{array}{l}\text { Modulus } \\
(\mathrm{MPa})\end{array}$ & $\begin{array}{l}\text { Tensile } \\
\text { Strength } \\
(\mathrm{MPa})\end{array}$ & $\begin{array}{l}\text { Elongation- } \\
\text { at-Break }(\%)\end{array}$ & $\begin{array}{l}\text { Toughness } \\
\left(\mathrm{MJ} / \mathrm{m}^{2}\right)\end{array}$ \\
\hline $\begin{array}{l}\text { Crosslinked protein- } \\
\text { surfactant-poly(n-butyl } \\
\text { acrylate) }\end{array}$ & $6.0 \pm 0.4$ & $2.3 \pm 0.2$ & $166 \pm 17$ & $2.1 \pm 0.4$ \\
\hline Protein-surfactant complex & $50 \pm 14$ & $2.5 \pm 0.5$ & $35 \pm 5$ & $0.6 \pm 0.3$ \\
\hline $\begin{array}{l}\text { Crosslinked poly(n-butyl } \\
\text { acrylate) }\end{array}$ & $0.460 \pm 0.015$ & $0.30 \pm 0.07$ & $140 \pm 30$ & $0.27 \pm 0.07$ \\
\hline
\end{tabular}

Table S4. Swelling ratio of blend and copolymers prepared with protein with various levels of methacrylation. All materials are comprised of protein, surfactant, and n-butyl acrylate at a ratio of 1:1:2, and were swollen in DMSO.

\begin{tabular}{|l|c|}
\hline $\begin{array}{l}\text { Average methacrylate groups } \\
\text { per protein }\end{array}$ & Swelling ratio \\
\hline 0 & ND $^{*}$ \\
\hline 1.2 & $3.21 \pm 0.1$ \\
\hline
\end{tabular}




\begin{tabular}{|l|l|}
\hline 3 & $3.09 \pm 0.03$ \\
\hline 6 & $2.52 \pm 0.11$ \\
\hline
\end{tabular}

*Swelling ratio not reported for the blend as the swollen material lost structural integrity and may have partially dissolved. 